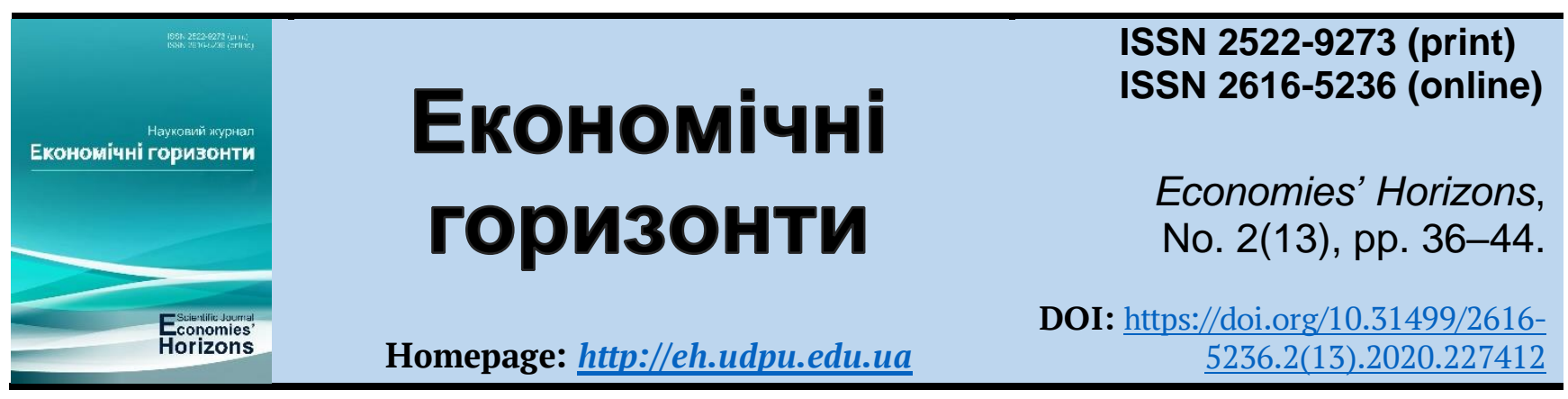

UDC 316.42:001.895

\title{
Innovations as a necessary condition of social development
}

Received: 5 May 2020

Accepted: 10 June 2020

\author{
Inna G. Gonchar ${ }^{1}$, Cand. Ped. Sc.
}

Gonchar, I. G. (2020), "Innovations as a necessary condition of social development", Economies' Horizons, no. 2(13), pp. 36-44. doi: https://doi.org/10.31499/2616-5236.2(13).2020.227412

Abstract. The purpose of the study was to identify and characterize the factors that affect the efficiency of innovations implementation in the social development. Methodology. It was possible to characterize the essence and content of innovations in the social development, to identify factors that affect the efficiency of innovations implementation in the social development through the use of the methods of analysis, systematization, comparison, confronting, generalization of scientific literature and legal and regulatory framework. Results. It was found that in a broad meaning, scientists considered the social development as a change in society, resulting in new social relations, institutions, norms and values. In a narrow meaning, the social development could be seen as a change in the social structure, individual institutions of the society, as a result of which they appeared themselves in a new state. At the same time, the characteristic features of the innovative social development were: novelty for the social environment in which it was implemented; focus on meeting current social needs, solving social problems; had a practical nature of the development, involved the implementation of ideas; transformation of social relations. It was established that innovations in today's conditions were a basic condition of the social development which provided both innovative ideas and innovative methods, ways, technologies of their application. The key factors of the innovative social development were identified: legal support and financial assistance, favorable social and economic conditions, innovative resources, critical mass. It was found that efficiency in the implementation of the innovative social development could be achieved through the accumulation of human potential and economic support; formation of the corresponding legislative, financial, economic base; increasing the social activity of young people; modernization of social infrastructure; introduction of innovative technologies, etc. Practical importance. We hope that the results of the study, our observations and comments will contribute to the effective implementation of innovations in the social development, will help to create the necessary conditions, to develop appropriate measures to regulate the activity. Prospects for further study. In our opinion, the issues of factors influencing the quality of human potential, mechanisms of implementing social innovations, etc. can be further developed.

Keywords: innovations, social development, innovative resource, legal support, financial assistance, social and economic conditions.

JEL Classification: O31, O32, O35.

Number of references: 22; number of tables: 0; number of figures: 0; number of formulas: $\mathbf{0 .}$

${ }^{1}$ Pavlo Tychyna Uman State Pedagogical University; Senior Lecturer at the Department of Social Pedagogy and Social Work; ORCID ID: http://orcid.org/0000-0002-4316-8650; e-mail: gigonchar@gmail.com. 


\title{
Інновації як необхідна умова соціального розвитку
}

\author{
Інна Григорівна Гончар ${ }^{1}$, к. пед. н.
}

Стаття надійшла: 05.05.2020

Стаття прийнята: 10.06.2020
Gonchar I. G. Innovations as a necessary condition of social development. Економічні горизонти. 2020. № 2(13). C. 36-44. DOI: $10.31499 / 2616$ 5236.2(13).2020.227412

Анотація. Мета дослідження. Мета статті полягає у вивченні проблем соціального розвитку та місця й ролі в цьому процесі інновацій. Методологія. Завдяки використанню методів аналізу, систематизації, порівняння, зіставлення, узагальнення наукової літератури й нормативноправової бази вдалося схарактеризувати суть та зміст інновацій в соціальному розвитку, визначити фактори, які впливають на ефективність впровадження інновацій в соціальному розвитку. Результати. Встановлено, що у широкому сенсі науковці розглядають соціальний розвиток як зміну суспільства, в результаті якої виникають нові суспільні відносини, інститути, норми та цінності. У вузькому сенсі соціальний розвиток можна розглядати як зміну соціальної структури, окремих інститутів суспільства, в результаті чого вони опиняються у новому стані. Водночас характерними ознаками інноваційного соціального розвитку є: новизна для соціального середовища, у якому впроваджується; орієнтація на задоволення актуальних соціальних потреб, вирішення соціальних проблем; має практичний характер розробки, передбачає втілення в життя ідей; трансформація суспільних відносин. Встановлено, що в умовах сьогодення інновації є базовою умовою соціального розвитку, які передбачають як інноваційні ідеї, так й інноваційні методи, способи, технології їх застосування. Визначено ключові фактори інноваційного соціального розвитку: правове забезпечення та фінансова підтримка (як ключове джерело фінансової та правової допомоги в реалізації інноваційних соціальних ініціатив), сприятливі соціально-економічні умови (виступають базою соціального розвитку), інноваційний ресурс (наявність людського ресурсу та матеріального забезпечення), критична маса (як прошарок суспільства, який буде активним споживачем впроваджених інновацій). Доведено, що ефективності в реалізації інноваційного соціального розвитку можна досягнути шляхом накопичення людського потенціалу та матеріального забезпечення; формування відповідної законодавчої, фінансової, матеріальної бази; підвищення соціальної активності молоді; модернізації соціальної інфраструктури; запровадження інноваційних технологій та ін. Практичне значення. Результати проведеного дослідження, спостереження та висновки сприятимуть ефективному впровадженню інновацій у соціальний розвиток, допоможуть створити необхідні умови, розробити відповідні заходи щодо державного регулювання. Перспективами подальших досліджень можуть стати дослідження розвитку факторів, що впливають на якість людського потенціалу, механізмів впровадження соціальних інновацій тощо.

Ключові слова: інновації, соціальний розвиток, інноваційний ресурс, правове забезпечення, фінансова підтримка, соціально-економічні умови.

Кількість джерел: 22; кількість таблиць: 0; кількість рисунків: 0; кількість формул: 0.

\section{Introduction.}

Exacerbation of social challenges is typical for modern Ukraine. This problem became especially relevant in connection with the annexation of Crimea and the beginning of military actions in eastern Ukraine, and the whole world faced a new challenge in 2020 COVID-19. Issues that seemed to work unconditionally for a large part of the population became significant - existence, protection of

\footnotetext{
${ }^{1}$ Уманський держсавний педагогічний університет імені Павла Тичини; старший викладач кафедри соиіальної педагогіки та соціальної роботи; ідентифікатор ORCID: http://orcid.org/0000-0002-4316-8650; e-mail: gigonchar@gmail.com.
} 
their own lives. In addition, most of the Ukrainian society lives below the poverty line, which is negatively reflected in the level of the society development and requires the efforts of the state in the direction of social development. However, there is no single way to solve complex social problems, so the innovative approach is important as a tool for creating new ideas, services and possibilities. Innovations in the social development are the requirement of time, the implementation of which involves the use of better solutions that meet the new needs of society. Social innovations have a two-way effect: on the one hand, they are focused on the development of society, and on the other hand, they expand opportunities for people's social activity.

\section{Literature review.}

The problem of creating decent living conditions for every citizen in Ukraine, and hence the management of the social development, is at the peak of urgency. The study on the strategy of social policy of Ukraine (Volska and Pankratieva, 2018); the study of peculiarities of the social development (Melnychuk, 2015; Reshetnichenko, 2012; Skurativskyi, Troshchynskyi, Sytnuk et al., 2009); the implementation of innovations in various spheres of life (Unceta, Castro-Spila and Fronti, 2017; Chukhrai and Patora, 2006; Khachaturian, 2005; Silvestre and Țîrcă, 2019; Westley, McGowan and Tjörnbo, 2017); the principles of measuring social progress (Urama and Achempong, 2013) attracts attention in the field of the social development among the scientific publications of recent years. However, it is necessary to clarify the concept of innovation in the social development, to reveal all aspects of this process and to determine the factors of its success.

\section{Methods.}

A set of methods was used during the study: analysis, systematization, comparison, confronting, generalization of scientific literature and legal and regulatory framework which allowed characterizing the essence and content of innovations in the social development, identifying factors that affect the efficiency of innovations implementation in the social development.

\section{Research objectives.}

To reveal the essence of the concept of innovation, social development and its key aspects; to identify and characterize the factors that affect the efficiency of innovations implementation in the social development.

\section{Results and discussions.}

In recent years, there was a growing worldwide interest in the social innovations as a way to achieve sustainable economic growth. In the United States, Barack Obama, the President, developed the Social Innovation Fund which provided grants for promising programs. In South Korea, Park On-sung, the former Seoul Mayor, integrated approaches to the social innovations in the city government. In Europe, the European Commission developed recommendations to stimulate social innovations and spread them across the whole continent. In the United Kingdom, initiatives such as "the Greater Society" are formed to seek and spread the best social innovation (Urama and Achempong, 2013). In 2010, "the Europe 2020" strategy covering 28 countries was adopted. The task that formed the basis of the strategy was to overcome the consequences of the 2008 economic crisis. One of the key initiatives in the paper was to improve the financing of scientific researches and innovations to ensure that innovative ideas could be transformed into new products and services (European commission, 2020).

Over the past 5 years, the United Nations Development Program focused significantly on implementing of the social innovations in European countries. In fact, Ukraine was actively involved in the work on development of such an important area which was manifested in a number of implemented activities and social projects. It was worth noting that the International Conference of the Ukrainian Forum of Philanthropists holding annually focused on the problem of the social innovations: how to find new approaches, fresh ideas and untested prospects; what can be learnt from the creative developments of those who have already 
managed to do something like this, find success or gain useful experience, even from unsuccessful attempts. In addition, a social innovation camp was organized in 2017, and in 2019 a program U-Inn 2.0 RELOAD for the development of youth innovations, technological and creative solutions to promote integrity and inclusiveness in the regions of Ukraine was started. Thus, a significant number of programs and projects are conducted and implemented in Ukraine, which are focused on the social development of society, and one of the key conditions in this direction is their innovative aspect.

Ukraine in 2019 was ranked 80th of the "Social Development Index" rating among 149 countries in the world according to the results of a global study developed by the American non-governmental organization Social Progress Imperative with the support of "Deloitte" Company. The overall score was based on scores that included basic human needs (satisfaction level of basic human needs), basics of well-being (level of human health and environment development that ensured a prosperous life), possibilities (level of the development of the social institutions that created conditions for personal development) (Social Progress Imperative, 2020). This position of Ukraine put it on a par with countries where the level of social development was above average, which meant that the state was only paving the way for high standards of providing the quality of life.

Thus, we could speak about the steady interest of the whole civilized world to the issue on creating and spreading of the social innovations. In fact, such interest was explained by the fact that the social innovations provided the opportunity to move away from narrow stereotypical thinking in the field of social policy, charity, development of social institutions, etc., thus changing the basic practices, resources and structure of the social development.

The concept of the social development in the scientific literature was considered as:
- the result of social policy, changes in the social sphere which corresponded to the main world indicators of quality and standard of living (Reshetnichenko, 2012, p. 17);

- changes in society characterized by the transition of all social relations to a qualitatively new state (Skurativskyi, Troshchynskyi, Sytnuk et al., 2009, p. 7);

- the life of mankind and its constituent parts (races, megaethnoses, ethnic groups, subethnoses) in the natural environment, which was due to both the freedom of human will and objective laws (Shchokin, 2006, p. 3);

- activity that would improve the content of state influence on social processes, remark promising areas of the state social policy ( $\mathrm{Mel}$ nychuk, 2015, p. 58);

- a dynamic process of changes in the social, economic, humanitarian, political spheres of society (Prokopenko and Tarasenko, 2014, p. 75);

- the main part of social-and-economic development which was primarily aimed at forming the social policy of the country which aimed to mitigate the negative effects of individual and social inequality, social-and-economic shocks in society (Volska and Pankratieva, 2018);

- work in the result of which the life of whole society: conditions, level and quality of life of all social groups gradually and steadily got better (at least did not worsen), its social structure and functions improved (Volgin (ed.), 2008, p. 160).

Thus, several areas in the interpretation of the concept of the social development could be identified. In a broad sense, researchers saw it as a change in society, resulting in new social relations, institutions, norms and values. In a narrow sense, the social development could be seen as a change in social structure, individual institutions of society, as a result of which they found themselves in a new state. At the same time, a constant characteristic of the social development is, as a rule, its inevitability of changes, the transition from lower to higher levels and, as a consequence, dynamism. The new qualitative and quantitative state of the 
object in this case could be determined as the result of the social development. However, it should be noted that the efficiency of the social development could not be estimated immediately, but only after a certain time, analysing the standard of society life.

V. Kapitan noted that the social development could be objective or subjective, expressed in a specific or abstract form, determined by internal or external factors, connected with structural or functional changes, quantitative or qualitative, progressive or regressive (Kapitan, 2012). Analysing the sources on the studied problem, we considered it necessary to supplement this list with two more characteristic features - imitation and innovation factors. In fact, innovations involved the search for new ways to solve the problem, which was the opposite in meaning to the imitation form. An innovative approach required that we should be ready to go out of our daily procedures, review and analyse new approaches to the set tasks, look for new approaches and forms of work.

At the same time, the very concept of innovation had a multidimensional meaning, as it consisted of two forms: the idea and the process of practical implementation. And here the idea itself and ways of its realization, and a combination of new ideas with new ways of implementation could be innovative. In the scientific literature, the concept of innovation was usually interpreted as:

- a set of interconnected and interacting innovators-producers, innovative activity or innovative products (Nesterov, 2007);

- the use of new ideas for the organization by implementing them in goods, processes, services or management systems operated by the organization (Chukhrai and $\mathrm{Pa}$ tora, 2006, p. 12);

- implementation of new developments into the processes of production and management that could raise the efficiency of the activity of enterprises and institutions, as well as increase the degree of satisfaction of consumer needs (Romanchyk, 2014, p. 141);
- innovations based on the scientific-andtechnological progress consisting in the restoration of fixed assets and technologies, improvement of management and enhancement of the economic condition of enterprises and was the basis for economic growth of the national economy (Harnyk, 2018, p. 14);

- practical application of ideas (knowledge) to develop new or improved products, processes, methods and/or services (Unceta, Castro-Spila and Fronti, 2017, p. 411);

- the end result of the activity embodied in the form of a new or improved product introduced on the market, a new or improved technological process used in practice, or in a new approach to social services (Khachaturian, 2005, p. 6).

At the same time, the Law of Ukraine "On Innovation" defined innovations as newly created (applied) and (or) improved competitive technologies, products or services, as well as organizational-and-technical solutions of production, administrative, commercial or other nature that significantly improved the structure and quality of production and (or) the social sphere (The Verkhovna Rada of Ukraine, 2002). Thus, innovation should be considered as a process of developing the technology for innovation implementation, as a tool to achieve benefits, as a phenomenon permeating all aspects of human life, as the end result of the innovative activity, as a determinant of social development.

Analysis of the literature on the content of the concepts of innovation and social development made it possible to determine that innovation in the social development was a dynamic process based on the activity of innovation implementing, resulting in gradual and steady changes that led to the improvement of living conditions of the whole society, implementation of progressive ideas and services with the aim to solve social problems.

Actually, it was necessary to single out the characteristic features of the innovative social development: 
- novelty for the social environment in which it was implemented;

- focused on meeting current social needs, solving social problems;

- had a practical nature of development, provided for the implementation of ideas;

- provided for the transformation of social relations.

Increased interest to the innovations in the social development was appropriate, because they were aimed at solving current problems of the society in the most effective way. It was innovative social development that could contribute to the spread of positive changes in the society life, given that it was based on a constant search for information and resources and the use of new ways in a particular area.

Innovative activity had two directions: internal and external. The internal direction involved learning and rethinking of own activity, the quality of providing services. External direction - the opportunity to know and study innovations from the outside, the ability to use advanced innovative technologies developed and tested by experts from other countries in own activity.

At the same time, C. Bulut, H. Eren, D. Halac distinguished social innovations of two levels: micro-level and macro-level. The main purpose of social innovations at the micro-level was to meet social needs, improve living standards, enrich the capabilities of individuals or groups of people and others. At the macro-level, social innovations were connected with general changes in the society, the elimination of social inequality and ensuring of sustainable development (Bulut, Eren and Halac, 2013, p. 123).

Taken into account the definition, there were generally three common features of social innovations - the need, effective solution and benefits of this solution at the individual, organizational or societal levels (Bulut, Eren and Halac, 2013, p. 123). Therefore, first of all it was necessary to develop the idea that could be considered as social innovation. Another important aspect was that this innovation should lead to positive changes. The last necessary component was that this social innovation had to be accepted or internalized when it concerned applying.

Neumeier S. noted that the creation of innovations had to meet all of the following criteria:

1) it is innovative with regard to the user, context or application;

2) it meets needs more effectively than pre-existing alternatives;

3) it provides long-term solutions;

4) it is adopted beyond the initial group/network that developed it (Neumeier, 2017, p. 35).

In fact, the creation and spreading of innovations could take place in the following sectors:

- state (initiation and development of innovative projects by public authorities);

- public (creation and spreading of innovations by public organizations);

- private (personal development of innovative ideas).

It is worth noting that in today's conditions in Ukraine, innovations developed by the private or public sectors are becoming especially relevant, because they are the key subjects of changes in the country.

Given the relevance and necessity of innovations implementation, especially in the field of the social development, we consider it appropriate to identify the factors that affected the efficiency of this process:

Legal support and financial assistance. This item is implemented through the adoption of laws, presidential decrees, bylaws in the form of Government resolutions, orders of central executive bodies, etc. Today there are about 200 documents in the field of scientificand-technical and innovative activities: the Constitution of Ukraine, the Commercial Code, the Law of Ukraine "On Innovation", the Law of Ukraine "On Priority Areas of Innovation in Ukraine", the Law of Ukraine "On Investment", the Law Of Ukraine "On scientific and scientific-and-technical activity" and other normative legal acts. All of them are 
designed to create appropriate legal, economic and organizational principles of the state regulation of innovative activity in Ukraine, to regulate the mechanisms for obtaining funding for the project realization. It is important to understand that countries with a low level of innovative development need legislative support for innovations funding. Legislative support of the social innovations should be focused on: a conscious and systematic approach to the social development; transition from human resources management to building the innovative potential of society; support of the social innovations in the private and public sectors; creating initiatives not for people, but with people on the basis of co-creation and complicity.

Favourable social and economic conditions. In determining this factor, we first of all mean the resource conditions of the innovative development, a set of necessary and sufficient conditions connected with both economic and non- economic resources. These include: demographic situation, natural-and-climatic conditions, availability of the necessary economic and scientific-and-technical infrastructure; availability of highly qualified specialists and opportunity to improve their professional level; availability of financial institutions, availability of financial resources. It is necessary to have access to human, financial and other types of capital for the development of a social innovation project, which implies the need for an appropriate level of the economic development to intensify the activity for the development and implementation of the social innovations. At the same time, social tension, poverty, and insecurity of the population are motivators for the social innovations initiated by citizens. Thus, social and economic conditions can be both a barrier to the development of the social innovations and a stimulating factor.

Innovative resource. We identify two types of resources within this factor: human and economic. The level of the human capital development is one of the most important because it provides a flow of new knowledge. The high level of staff competence stimulates active participation in the innovation process, forms innovative competitiveness. In the case of the social innovations, human capital plays the most important role, beginning from the initiation stage, where knowledge and skills are used to identify social problems and to the development and simulation of the social innovations. It is important to accumulate innovative human resources by implementing initiatives in the education system, increasing the share of the population with higher education, involving specialists in the scientific researches, organizing international internships. At the same time, the innovative infrastructure is an extremely important aspect of the innovative social development. In fact, it is a set of interconnected structures that serve and ensure the implementation of innovative projects.

The presence of critical mass. It is important to form a circle of consumers of the social innovation, to create an appropriate institutional environment for the development of innovative activity and to promote the demand for innovative products. The innovation used by a narrow circle of people is doomed to failure. However, the innovation, which was spread among the general public, contributes to its popularization and further promotion. The formation of a critical mass is possible through advertising and direct involvement of consumers in the implementation of the social innovation. That is why it is so important to educate socially active young people who are able to think critically and develop new creative ideas. It is such young people who can become the subject of social changes, and therefore the critical mass that will support and develop all the positive changes in the country.

\section{Conclusions.}

Thus, in today's conditions, innovation is a basic condition of the social development, which provides both innovative ideas and innovative methods, ways and technologies of their application. We identified the following factors among the key factors of the innovative social development as: legal support and financial assistance (as a key source of financial and legal assistance in the implementation of 
the innovative social initiatives), favourable social and economic conditions (which are the basis of the social development), innovative resource (the presence of human resources and economic support), critical mass (as a layer of society that will be an active consumer of the implemented innovations). Thus, the efficiency of the innovative levers of the social development is realized by improving the characteristics of human potential and economic support: the formation of appropriate legislative, financial, economic base, increasing social activity of youth, modernization of the social infrastructure, implementation of the innovative technologies and others.

In fact, our conducted research does not cover all aspects of the problem. In our opinion, the issues of factors influencing the quality of human potential, mechanisms of implementing social innovations, etc. can be further developed.

\section{References}

Bulut, C., Eren, H. and Halac, D. S. (2013), "Social innovation and psychometric analysis", Procedia - Social and Behavioral Sciences, no. 82, pp. 122-130.

Chukhrai, N. I. and Patora, R. (2006), Tovarna innovatsiina polityka: upravlinnia innovatsiiamy na pidpryiemstvi [Commodity innovation policy: innovation management at the enterprise], Kondor, Kyiv, Ukraine, 398 p.

European commission (2020), "Communication from the commission. Europe 2020. A strategy for smart, sustainable and inclusive growth", available at: https://eur-lex.europa.eu/LexUriServ/LexUriServ.do?uri=COM:2010:2020:FIN:EN:PDF (Accessed 2 May 2020).

Harnyk, O. A. (2018), "Formation of an effective innovative model of economic development of Ukraine", Economies’ Horizons, no. 2(5), p. 12-19, doi: https://doi.org/10.31499/2616-5236.2(5).2018.140635

Kapitan, V. O. (2012), "The essence and role of social processes in providing of economic security", Demokratychne vryaduvannya, [Online], no. 10, available at: http://nbuv.gov.ua/UJRN/DeVr_2012 1026 (Accessed 2 May 2020).

Khachaturian, Kh. V. (2005), Innovatsiyi v derzhavnomu upravlinni [Innovations in public administration], NADU, Kyiv, Ukraine, 252 p.

Melnychuk, L. (2015), "Social development of regions as an object of managerial influence: terminological analysis”, Zbirnyk naukovykh prats "Efektyvnist derzhavnoho upravlinnia”, no. 43, pp. 58-64.

Nesterov, A. V. (2007), "Innovations: a systematic approach", Kompetentnost', [Online], vol. 6(47), available at: https://pravo.hse.ru/data/2010/02/10/1234989978/07060313.pdf (Accessed 2 May 2020).

Neumeier, S. (2017), "Social innovation in rural development: identifying the key factors of success", The geographical journal, vol. 183(1), pp. 34-46 doi: https://doi.org/10.1111/geoj.12180

Prokopenko, L. L. and Tarasenko, T. M. (2014), "Education and social development of young people as to influence state", Public Administration Aspects, no. 1-2 (3-4), pp. 70-76.

Reshetnichenko, A. V. (2012), Bazovi zasady sotsialnoho rozvytku [Basic principles of social development], NAPA, Kyiv, Ukraine, $52 \mathrm{p}$.

Romanchyk, T. V. (2014), “Theory of innovation: research of the conceptual apparatus”, Biznes Inform, no. 10, pp. 138-142.

Shchokin, H. V. (2006), Zakony sotsialnoho rozvytku i upravlinnia [Laws of social development and management], MAUP, Kyiv, Ukraine, 192 p.

Silvestre, B. S. and Ţîrcă, D. M. (2019), "Innovations for sustainable development: Moving toward a sustainable future”, Journal of Cleaner Production, no. 208, pp. 325-332, doi: https://doi.org/10.1016/j.jclepro.2018.09.244

Skurativskyi, V. A., Troshchynskyi, V. P., Sytnyk, P. K. et al. (2009), Upravlinnia sotsialnym i humanitarnym rozvytkom [Management of social and humanitarian development], NADU, Kyiv, Ukraine, $456 \mathrm{p}$.

Social Progress Imperative (2020), “2019 Social Progress Index. Ukraine”, available at: https://legacy.socialprogress.org/assets/downloads/scorecards/2019/en/UKR-Scorecard.pdf (Accessed 2 May 2020).

The Verkhovna Rada of Ukraine (2012), The Law of Ukraine "On innovation activity", available at: http://zakon4.rada.gov.ua/laws/show/40-15/card6 (Accessed 2 May 2020).

Unceta, A., Castro-Spila, J. and Fronti, J. G. (2017), “The three governances in social innovation”, Innovation: The European Journal of Social Science Research, vol. 30, no. 4, pp. 406-420, doi: https://doi.org/10.1080/13511610.2017.1279537 
Urama, K. C. and Achempong, E. N. (2013), “Social innovation creates prosperous societies”, available at: https://ssir.org/articles/entry/social_innovation creates prosperous societies (Accessed 2 May 2020).

Volgin, N. A. (ed.), (2008), Social'naja politika [Social policy], Jekzamen, Moscow, Russia, 943 p.

Volska, O. M. and Pankratieva, T. L. (2018). "Theoretical foundations of public administration of the modern state social development", Derzhavne budivnytstvo, [Online], no. 2, available at: http://www.irbishttp://nbuv.gov.ua/UJRN/DeBu 2018224 (Accessed 2 May 2020).

Westley, F., McGowan, K. and Tjörnbo, O. (eds.). (2017), The evolution of social innovation: Building resilience through transitions, Edward Elgar Publishing, Massachusetts, USA, 288 p. doi: https://doi.org/10.4337/9781786431158

Цей твір ліцензовано на умовах Ліцензії Creative Commons «/з Зазначенням Авторства - Некомериійна 4.0 Міжнародна» (CC BY-NC 4.0).

This is an open access journal and all published articles are licensed under a Creative Commons "Attribution-NonCommercial 4.0 International" (CC BY-NC 4.0). 